\title{
Lipolytic response of adipose tissue and metabolic adaptations to long periods of fasting in red tilapia (Oreochromis sp., Teleostei: Cichlidae)
}

\author{
WALTER DIAS JUNIOR ${ }^{1}$, AMANDA M. BAVIERA ${ }^{2}$, NEUSA M. ZANON ${ }^{3}$, VICTOR D. GALBAN ${ }^{3}$, MARIA \\ ANTONIETA R. GARÓFALO ${ }^{3}$, CELIO R. MACHADO ${ }^{3}$, ELISA F.L.C. BAILÃO ${ }^{4}$ and ISIS C. KETTELHUT ${ }^{3}$
}

\author{
${ }^{1}$ Laboratório de Fisiologia e Bioquímica Toxicológica, Faculdade de Enfermagem, Universidade Estadual de Goiás/ \\ UEG, Campus de Ceres, Rua Lucas Marcelino dos Santos, Qd34 Lt03, 76300-000 Ceres, GO, Brasil \\ ${ }^{2}$ Departamento de Análises Clínicas, Faculdade de Ciências Farmacêuticas de Araraquara, Universidade Estadual \\ Paulista Júlio de Mesquita Filho/UNESP, Rua Expedicionários do Brasil, 1621, 14801-136 Araraquara, SP, Brasil \\ ${ }^{3}$ Departamento de Bioquímica, Faculdade de Medicina de Ribeirão Preto, Universidade de São Paulo/ \\ FMRP-USP, Av. Bandeirantes, 3900, Monte Alegre, 14049-900 Ribeirão Preto, SP, Brasil \\ ${ }^{4}$ Faculdade de Farmácia, Universidade Estadual de Goiás/UEG, Câmpus Henrique Santillo, Campus \\ CCET, BR 153, 30105, Fazenda Barreiro do Meio, 75132-903 Anápolis, GO, Brasil
}

Manuscript received on August 7, 2015; accepted for publication on December 7, 2015

\begin{abstract}
Adaptive changes of carbohydrate and lipid metabolism induced by 7, 15, 30, 60, 90, 150 and 200 days of fasting were investigated in red tilapia (Oreochromis sp.). Plasma glucose, lactate and free fatty acids (FFA) levels, liver and muscle glycogen and total lipid contents and rates of FFA release from mesenteric adipose tissue (MAT) were measured. Plasma glucose levels showed significant differences only after 90 days of fasting, when glycemia was $34 \%$ lower $\left(50 \pm 5 \mathrm{mg} \cdot \mathrm{dL}^{-1}\right)$ than fed fish values $\left(74 \pm 1 \mathrm{mg} \cdot \mathrm{dL}^{-1}\right)$, remaining relatively constant until 200 days of fasting. The content of liver glycogen $(» 15 \%)$ in fed tilapia fell $40 \%$ in 7 days of food deprivation. In 60, 90 and 150 days of fasting, plasma FFA levels increased $49 \%, 64 \%$ and $90 \%$, respectively, compared to fed fish values. In agreement with the increase in plasma FFA, fasting induced a clear increase in lipolytic activity of MAT incubated in vitro. Addition of isobutylmethylxanthine (cAMP-phosphodiesterase inhibitor) and isoproterenol (non selective beta adrenergic agonist) to the incubation medium induced a reduction of lipolysis in fasted fish, differently to what was observed in mammal adipose tissue. This study allowed a physiological assessment of red tilapia response to starvation.
\end{abstract}

Key words: adipose tissue, adrenoreceptor, lipolysis, liver glycogen.

\section{INTRODUCTION}

The ability to use carbohydrate for energy varies greatly among fish species and it is generally related to the feeding habitats of the species (NRC 2011).

Correspondence to: Walter Dias Junior

E-mail: walter.dias@ueg.br
In contrast, fish present a relative efficiency in lipid and protein digestion (Clements and Raubenheimer 2006). In this way, in general fish use preferentially lipids and proteins as main source of energy, because carbohydrates are usually metabolized very slowly and are not so well absorbed from the diet (Li and Robinson 2015, Hung and Storebakken 
1994, Machado et al. 1989, Nagay and Ikeda 1972). Fish lipids are found scattered in hepatic tissue, muscle (main red muscle) and in mesenteric tissue involving the gut (Machado et al. 1989), and these site of deposition are species-dependent (Weil et al. 2013). Adipose tissue is distributed in the abdominal cavity located periviscerally in many fish species, including tilapia, and the morphology and distribution of adipose cells in visceral fat and muscle of tilapias are still not clear (Albalat et al. 2005).

Despite the presence of appreciable amounts of organized fat tissue in several species, information about the regulation of the lipolytic activity in fish species when compared to mammals are sparse (Albalat et al. 2005). Mammals lipolytic hormones, like catecholamines and glucagon, did not change fatty acids mobilization on adipose tissue from fish, amphibian and reptiles (Farkas 1967, Migliorini et al. 1992). However, Migliorini et al. (1992) found that the in vitro lipolytic activity of Hoplias malabaricus adipose tissue was markedly increased in the presence of cAMP analogues or xanthine derivatives, which inhibit cAMPphosphodiesterase, increasing the intracellular concentration of cAMP. Moreover, Magnoni et al. (2008) found that the in vivo lipolysis was inhibited after norepinephrine administration $(0.45 \mathrm{nmol}$. $\left.\mathrm{Kg}^{-1}\right)$ in rainbow trout for 10 minutes.

Many studies were carried out in fish to investigate the mechanism by which catecholamines modify lipolysis via direct activation of adipocyte alpha and/or beta-adrenoceptors. Previous studies demonstrated the role of beta-adrenoceptors in lipolysis inhibition or stimulation in fish, indicating a novel phenomenon and a different mechanism from that described in mammals, since in these animals the beta-adrenoceptors stimulation results just in lipolysis increase (Magnoni et al. 2008, Van Raaij et al. 1995, Van Den Thillart et al. 2001, Vianen et al. 2002). But the participation of adrenoceptors in lipolytic response of fish adipose tissue appears to be variable and dependent on fish species. In Oreochromis mossambicus (common tilapia) and in Cyprinus carpio (carp) beta1-adrenoceptors inhibit and beta2-adrenoceptors stimulate lipolysis in adipose tissue (Van Den Thillart et al. 2001, Vianen et al. 2002). Furthermore, Vianen et al. (2002) showed the participation of beta3-adrenoceptors in the inhibition of free fatty acids (FFA) mobilization from adipose tissue in tilapia. A fall in plasma FFA levels after norepinephrine action in C. carpio was observed (Van Raaij et al. 1995, Van den Thillart et al. 2001), but alpha2-adrenoceptor antagonist blocked the norepinephrine effect (Van Den Thillart et al. 2001). Vianen et al. (2002) found that norepinephrine induces a reduction of adipocyte FFA release in O. mossambicus and that the addition of phentolamine (alpha1- and alpha2-adrenoceptor antagonist) did not affect this mechanism.

It has been described that external factors could also regulate the lipolysis activity in fish. Fasting increased the lipolysis activity of gilthead seabream visceral adipocytes starved for 11 days (Albalat et al. 2005). In rainbow trout, it was observed a visceral fat depletion and a reduced expression of genes involved with triacylglycerol breakdown in 6 week of fasting (Kittilson et al. 2011). Fish, in general, have such ability to withstand long periods of fasting (Navarro and Gutiérrez 1995, Vigliano et al. 2002), since prolonged drought periods, reproductive process or prey availability are responsible for the natural process of fasting (Caruso et al. 2010, Pérez-Jiménez et al. 2012). Farmed fish may also experience fast situations imposed by routine procedures in aquaculture, as those used to avoid risks of overproduction (Krogdahl and Bakke-McKellep 2005).

Tilapias are the ninth most important aquaculture species group and the second most important fish group species in terms of weight of production worldwide. The name tilapia includes many species of the Oreochromis Genus. These fish are endemic to Africa and the Middle East, but 
they have been introduced into most tropical and subtropical countries (Boyd 2004). The Brazilian aquaculture is the second (Chile is the first one) in South American production, supported basically by production chains of shrimp and tilapia culture. Brazil has genetically improved tilapia strains to better adaptation to local climatic conditions (Scorvo Filho et al. 2010).

Due to the large number of controversial results concerning fish lipolysis regulation, and the commercial importance of tilapia culture in Brazil, whose drought periods are prolonged, the objective of this work was to investigate the metabolic adaptation of red tilapia to long periods of fasting. It was investigated the fatty acid mobilization in vivo and the lipolytic response in vitro to alpha and beta adrenoceptors of the mesenteric adipose tissue. Agonists and antagonists inhibitors of cAMP, forskolin, phosphodiesterase (isobutylmethylxanthine), theophyline, and activators of adenylate cyclase were also investigated. Blood glucose and lactate levels, glycogen and lipids content in liver and white muscle were also measured.

\section{MATERIALS AND METHODS}

\section{MAINTENANCE OF ANIMALS}

This study agrees with Ethical Principles in Animal Research adopted by Brazilian College of Animal Experimentation (COBEA) and was approved by the Ethical Committee for Animal Research (CEEA) of Universidade de São Paulo (USP).

Adult male red tilapias (Oreochromis sp.), weighting 400-500 g were supplied by Aquaculture Center, Usina São Geraldo, Sertãozinho, São Paulo, Brazil. Fish were acclimated in 8 aquaria of $250 \mathrm{~L}$ (10 fish/aquarium) with indoor recirculation system, equipped with a mechanical and biological filtering system, in 12:12 h (light:dark) photoperiod, controlled temperature at $28 \pm 1{ }^{\circ} \mathrm{C}$ for at least two weeks before experiments. All aquaria were connected and linked to same filtering system. The water of this system was maintained with $5 \mathrm{mg}$ $\mathrm{O}_{2} \cdot \mathrm{L}^{-1}$ and $\mathrm{pH} \sim 7.0$. All the experiments were done between 8:00-10:00 h.

The fish were kept without food for 7, 15, 30, $60,90,150$ and 200 days ( $n=10$ for each fasting period). For control, fish were daily fed for 7 , $15,30,60,90,150$ and 200 days $(n=10$ for each feeding period) at $2 \%$ of body weight per day with commercial pelleted fish food (Laguna) $10 \mathrm{~mm}$ diameter (protein: 28\%; lipids: 6\%; fibers: $10 \%$; minerals: $9 \%$; $\mathrm{Ca}^{++}$: 3\%; P: $0.5 \%$; moisture: $8 \%$ ). The data presented in this paper about the control fish were obtained by a mean of all the feeding periods, since a statistical difference between all the control groups used in this work was not observed using ANOVA.

\section{BODY AND TISSUE PARAMETERS OBTAINMENT}

The fish were sacrificed by rapid spinal transection at cervical level and, then, the animals were eviscerated for removal of liver, gonads, stomach, gut and mesenteric adipose tissue (MAT), which were immediately weighted to get somatic indices. The condition factor was determined using the formula: $\left(\mathrm{B}_{\mathrm{W}} / \mathrm{S}_{\mathrm{L}}{ }^{3}\right) \times 100$, where $\mathrm{B}_{\mathrm{W}}$ is body weight and $S_{L}$ is standard length. Hepatosomatic index was determined using the formula: (liver weight/ fish weight) $x$ 100. Gonadosomatic index was determined using the formula: (Gonad weight /fish weight) $x$ 100. Stomach and gut somatic index was determined using the formula: (Stomach and gut weight/fish weight) $\mathrm{x}$ 100. MAT somatic index was determined using the formula: (MAT weight /fish weight) x 100 .

\section{Plasma Metabolite LeVEls Determination}

Blood samples of live fish were collected from the caudal vein into ice-cooled, heparin-flushed syringes that were placed immediately on ice. Blood glucose, lactate and FFA levels were determined following methods of glucose-oxidase (Bergmeyer et al. 1974) and methods described by Clark et al. (1984) and Dole and Meinertz (1960), respectively. 
GLYCOGEN AND TOTAL LIPIDS CONTENT IN LIVER AND MUSCLE DETERMINATION

After the fish sacrifice, liver and white muscle fragments, removed from left side of body fish at the anal fin level, were taken to immediate measure of glycogen and total lipids content according to Carrol et al. (1956) and Bligh and Dyer (1959), respectively.

\section{MAT EXCISION AND in vitro INCUBATION PROCEDURE}

MAT was dissected free from connective tissue and blood vessels for the in vitro incubation experiments. After spinal cross cutting, samples of MAT were rapidly removed and portions of 5-20 g.fish ${ }^{-1}$ were obtained. The adipose tissue was placed immediately into a Petri dish with KrebsHenseleit buffer (in mM: $118.5 \mathrm{NaCl} ; 4.75 \mathrm{KCl} ; 1.2$ $\mathrm{MgSO}_{4} ; 1.91 \mathrm{CaCl}_{2} ; 1.2 \mathrm{KH}_{2} \mathrm{PO}_{4} ; 25 \mathrm{NaHCO}_{3} ; 0.5$ D-glucose; $\mathrm{pH}$ 7.4) at room temperature, and was carefully chopped with small scissors and sharp blades to obtain pieces of $\sim 2-5 \mathrm{~mm}^{2}$. To verify the mobilization of fatty acids from mesenteric adipose tissue, portions of chopped mesenteric adipose tissue $(\sim 500 \mathrm{mg})$ were incubated for $2 \mathrm{~h}$ at $37^{\circ} \mathrm{C}$ in $5 \mathrm{~mL}$ of Krebs-Henseleit buffer containing $2 \%$ fatty acid free BSA (bovine serum albumin) and equilibrated with $95 \% \mathrm{O}_{2}: 5 \% \mathrm{CO}_{2}$. This medium was called "BASAL". Tissues were incubated in constant shaking water bath, and triplicate flasks were run at each test. The mobilization of fatty acids was also measured, adding in BASAL medium, dibutyryl-cAMP (cAMP $10^{-3} \mathrm{M}$ ); isoproterenol (ISO $10^{-5} \mathrm{M}$ ), a non-selective beta-adrenoceptor agonist; 3-isobutyl-1-methylxanthine (IBMX $10^{-3} \mathrm{M}$ ), a cAMP-phosphodiesterase inhibitor; Forskolin $\left(\mathrm{FSK} 10^{-5} \mathrm{M}\right)$, an activator of the catalytic component of the adenylate cyclase system; Yohimbine (YHB $10^{-5} \mathrm{M}$ ), an alpha2-adrenoceptor antagonist; Adenosine deaminase (ADA) $(10 \mu \mathrm{g}$. $\mathrm{mL}^{-1}$ ), an enzyme that inhibits adipocytes lipolysis by activation of Gi protein; Prazosin (PZS $\left.10^{-5} \mathrm{M}\right)$, an alpha1-adrenoceptor antagonist; PZS $\left(10^{-5} \mathrm{M}\right)$ + YHB $\left(10^{-5} \mathrm{M}\right)$; Theophylline (THEO $\left.10^{-2} \mathrm{M}\right)$, a cAMP-phosphodiesterase inhibitor; Phenylephrine (PHE $10^{-5} \mathrm{M}$ ), a non-selective alpha-adrenoceptor agonist; $\operatorname{IBMX}\left(10^{-3} \mathrm{M}\right)+\mathrm{NaF}(10 \mathrm{mM})$, an inhibitor of GTPase activity associated with the alphasubunit of the Gs protein; Arterenol (NOR $10^{-5} \mathrm{M}$ ), a non-selective alpha and beta-adrenoceptor agonist. At the end of the experimental period, flasks were put on ice and FFA released was measured in the incubation medium according to Dole and Meinertz (1960).

\section{STATISTICAL ANALYSIS}

Data are expressed as mean \pm SEM, and Student's $t$ test was used for comparisons between means for: body weight, standard length, condition factor, weight gain, tissues weight and their somatic index, glycemia, free fatty acids, and liver and muscle glycogen. ANOVA analysis was used to compare the effects of the lipolytic agents during fasting. $p<$ 0.05 was taken as criterion of significance.

\section{RESULTS}

EFFECTS OF FASTING ON MORPHOLOGICAL PARAMETERS AND TISSUES WEIGHT

Condition factor and weight gain are presented on Table I. A significant fall in the condition factor was observed after 60 days of fasting (Table I). Moreover, during all the experimental period, the fed control animals gained weight (21\%) and the loss of body weight in fasted fish varied from $18 \%$ (7 days) to $45 \%$ (200 days of fasting).

Fasting for 15 days or more reduced the liver weight, but 7 days-fasting induced a significant decrease in hepatosomatic index (Table II). These index values continued to fall until 60 days of fasting, and then remained constant until 200 days. Gonad weight and gonadosomatic index were not significantly different during the whole experimental period (Table II). The whole period of 
fasting induced a decrease of $40-50 \%$ in stomach and gut weights and in their somatic index in comparison to fed animals (Table II). The MAT mass and its somatic index decreased only after 60 days of fasting (Table II), reaching values $60 \%$ lower than fed fish after 200 days of fasting.

TABLE I

Body parameters of fed and fasted red tilapias (Oreochromis sp).

\begin{tabular}{|c|c|c|c|}
\hline & & $\mathrm{C}_{\mathrm{F}}\left(\mathrm{g} \cdot \mathrm{cm}^{-3}\right)$ & $\mathrm{W}_{\mathrm{G}}(\%)$ \\
\hline \multicolumn{2}{|c|}{ Fed } & $3.32 \pm 0.03$ & $21 \pm 7$ \\
\hline \multirow{7}{*}{$\begin{array}{l}\text { Fasted } \\
\text { (days) }\end{array}$} & 7 & $3.42 \pm 0.14$ & $-18 \pm 3 *$ \\
\hline & 15 & $3.11 \pm 0.12$ & $-22 \pm 3 *$ \\
\hline & 30 & $3.01 \pm 0.06$ & $-22 \pm 4 *$ \\
\hline & 60 & $2.90 \pm 0.10^{*}$ & $-25 \pm 3 *$ \\
\hline & 90 & $2.96 \pm 0.07 *$ & $-28 \pm 5^{*}$ \\
\hline & 150 & $2.74 \pm 0.07 *$ & $-33 \pm 2 *$ \\
\hline & 200 & $2.79 \pm 0.08^{*}$ & $-45 \pm 4 * \#$ \\
\hline
\end{tabular}

$\mathrm{C}_{\mathrm{F}}$ : Condition Factor; $\mathrm{W}_{\mathrm{G}}$ : Weight Gain. Values represent mean $\pm \mathrm{SEM}$ $(\mathrm{n}=10$ fish for fed and for each fasting period $) .{ }^{*}(\mathrm{P}<0.05)$ vs Fed mean; $\#(\mathrm{P}<0.05) 200$ vs other fasted periods.

TABLE II

Tissue weight and their somatic index of fed and fasted red tilapias (Oreochromis sp).

\begin{tabular}{|c|c|c|c|c|c|c|c|c|c|}
\hline & & \multicolumn{4}{|c|}{ Tissue Weight (g) } & \multicolumn{4}{|c|}{ Somatic Index (\%) } \\
\hline & & L & $\mathrm{G}_{0}$ & $\mathrm{SG}$ & MAT & $\mathrm{H}_{\mathrm{SI}}$ & $\mathrm{G}_{\mathrm{oSI}}$ & $\mathrm{SG}_{\mathrm{SI}}$ & $\mathrm{MAT}_{\mathrm{SI}}$ \\
\hline & Fed & $8.9 \pm 0.3$ & $2.2 \pm 0.2$ & $13.6 \pm 1.7$ & $15.1 \pm 1.1$ & $2.27 \pm 0.07$ & $0.50 \pm 0.04$ & $2.90 \pm 0.39$ & $3.29 \pm 0.19$ \\
\hline \multirow{7}{*}{ 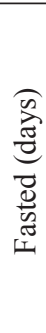 } & 7 & $7.1 \pm 0.5$ & $1.6 \pm 0.3$ & $8.2 \pm 0.4^{*}$ & $15.5 \pm 2.1$ & $1.55 \pm 0.11 *$ & $0.35 \pm 0.04$ & $1.78 \pm 0.12 *$ & $3.19 \pm 0.30$ \\
\hline & 15 & $4.6 \pm 0.4^{*}$ & $2.0 \pm 0.2$ & $7.7 \pm 0.4^{*}$ & $11.4 \pm 1.7$ & $1.22 \pm 0.09 *$ & $0.53 \pm 0.07$ & $1.79 \pm 0.06 *$ & $2.80 \pm 0.29$ \\
\hline & 30 & $4.6 \pm 0.3 *$ & $2.2 \pm 0.2$ & $7.4 \pm 0.5 *$ & $13.3 \pm 1.0$ & $1.08 \pm 0.05 *$ & $0.52 \pm 0.06$ & $1.62 \pm 0.10 *$ & $3.11 \pm 0.21$ \\
\hline & 60 & $4.6 \pm 0.4 *$ & $1.9 \pm 0.3$ & $7.1 \pm 0.4 *$ & $9.0 \pm 0.7 *$ & $1.04 \pm 0.12 *$ & $0.41 \pm 0.06$ & $1.54 \pm 0.08 *$ & $2.07 \pm 0.16 *$ \\
\hline & 90 & $5.4 \pm 0.3^{*}$ & $1.5 \pm 0.2$ & $7.3 \pm 0.5^{*}$ & $9.2 \pm 0.9 *$ & $1.05 \pm 0.04 *$ & $0.29 \pm 0.03$ & $1.46 \pm 0.08 *$ & $1.95 \pm 0.18 *$ \\
\hline & 150 & $4.5 \pm 0.5^{*}$ & $1.8 \pm 0.4$ & $6.9 \pm 0.8^{*}$ & $6.9 \pm 1.6^{*}$ & $1.06 \pm 0.07 *$ & $0.27 \pm 0.05$ & $1.56 \pm 0.17 *$ & $1.45 \pm 0.29 *$ \\
\hline & 200 & $5.1 \pm 0.6^{*}$ & $1.4 \pm 0.3$ & $7.4 \pm 0.8^{*}$ & $5.9 \pm 1.1 *$ & $1.05 \pm 0.08 *$ & $0.27 \pm 0.06$ & $1.53 \pm 0.15^{*}$ & $1.25 \pm 0.23^{*}$ \\
\hline
\end{tabular}

L: Liver; $\mathrm{G}_{\mathrm{o}}$ : Gonad; SG: Stomach and Gut; MAT: Mesenteric Adipose Tissue; $\mathrm{H}_{\mathrm{SI}}$ : Hepatosomatic Index; $\mathrm{G}_{\mathrm{oSI}}$ : Gonadosomatic Index; $\mathrm{SG}_{\mathrm{SI}}$ : Stomach and Gut Somatic Index; $\mathrm{MAT}_{\mathrm{SI}}$ : Mesenteric Adipose Tissue Somatic Index. Values represent mean $\pm \mathrm{SEM}$ $(\mathrm{n}=10$ fish for fed and for each fasting period). $*(\mathrm{P}<0.05)$ vs fed.

\section{EFFECT OF FASTING ON METABOLITE LEVELS}

Plasma glucose levels of fed fish $\left(74 \pm 1 \mathrm{mg}^{\mathrm{dL}} \mathrm{dL}^{-1}\right)$ did not change until 60 days of fasting (Fig. 1a). After 90 days, glycemia decreased significantly (34\%) in relation to fed fish, remaining low and constant thereafter $\left(\sim 50 \pm 5 \mathrm{mg} \cdot \mathrm{dL}^{-1}\right)$. Fasting for 60,90 and 150 days resulted in 49,64 and $90 \%$ increase of FFA plasma levels, respectively (Fig. 1b). After 200 days of fasting, FFA levels returned to control values (Fig. 1b). Lactate plasma level of fasted fish did not change significantly during the different periods of fasting in comparison to fed fish, ranging from $0.530 \pm 0.036$ (fed) to $0.716 \pm$ $0.059 \mathrm{mmol} . \mathrm{mL}^{-1}$ (200 days of fasting) (data not shown).

\section{GLYCOGEN AND TOTAL LIPIDS CONTENT IN LIVER AND MUSCLE}

The liver glycogen content in fed tilapia (15.0 \pm $0.4 \%$ ) decreased approximately $40 \%$ after 7 days of fasting (Table III). These values remained constant 
up to 60 days of fasting. After 90 to 200 days of fasting, the liver glycogen content fell to values $55 \%$ lower than fed state. Muscle glycogen content fell around $42.3 \%$ from 60 to 90 days of fasting, but did not change significantly in the other fasting periods tested in this work (Table III).

The total lipids content in fed tilapia liver $(10.5 \pm 0.4 \%)$ increased twice in 90 days of fasting (Table III), remaining constant until 200 days of fasting. No change was observed in total lipids content in tilapia muscle until 60 days of fasting (3.1 \pm $0.3 \%$ ); the values remained constant and similar to fed condition $(4.1 \pm 0.3 \%)$ (Table III). A significant decrease of muscle lipid content was only observed after 90 days $(2.7 \% \pm 0.2 \%)$, which continues to fall until 200 days of fasting $(1.5 \% \pm 0.1 \%)$.

\section{EFFECT OF FASTING ON MESENTERIC ADIPOSE TISSUE LIPOLYSIS in vitro}

Fatty acids mobilization from fragments of tilapia adipose tissue, incubated in control condition (BASAL medium), fasted for 60 to 200 days, was higher than FFA released from adipose tissue of fed fish and from adipose tissue of 7, 15 or 30 days fasted fish (Fig. 2). Similar results were also found when adipose tissue from all groups of fish was
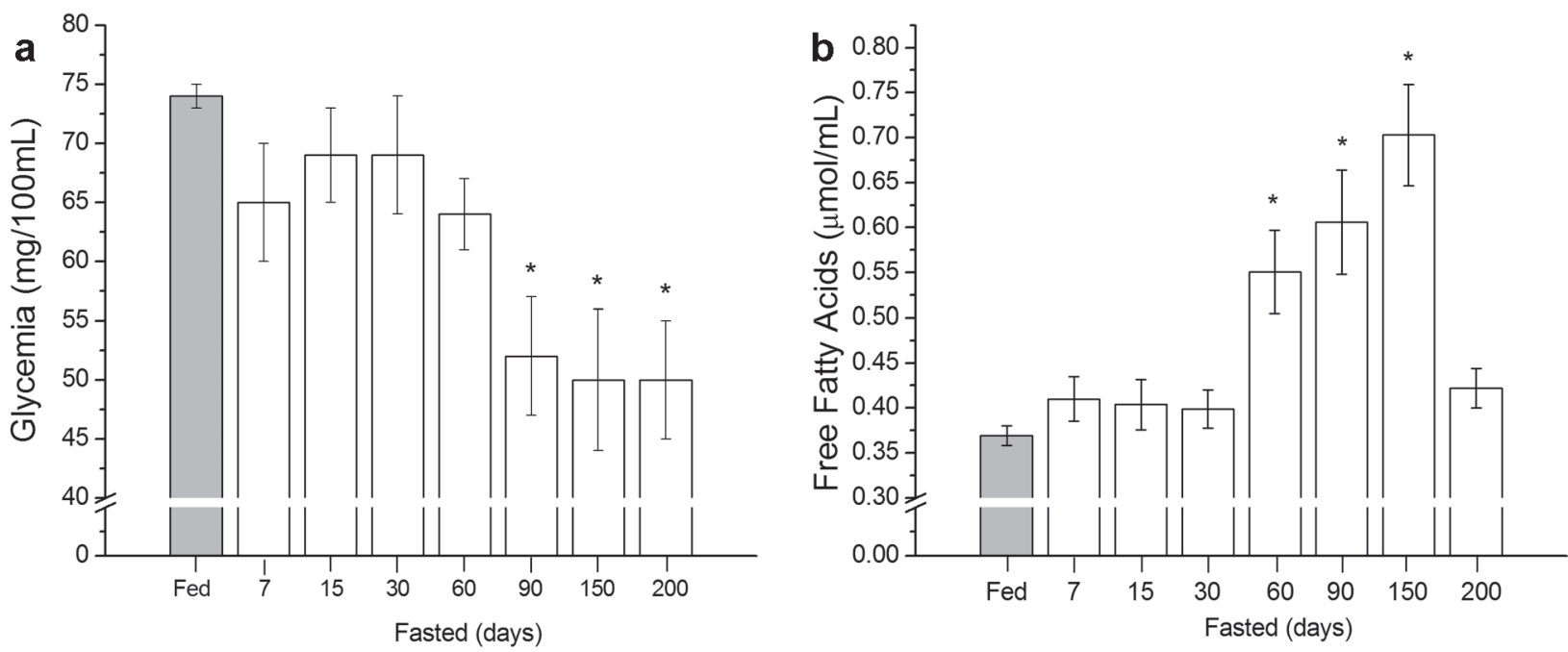

Figure 1 - Plasma metabolic parameters of fed and fasted red tilapia (Oreochromis sp). Glycemia (a) and free fatty acids (b) were evaluated. Values represent mean $\pm \operatorname{SEM}\left(\mathrm{n}=10\right.$ fishes for fed and for each fasting period). ${ }^{*}(\mathrm{P}<0.05)$ vs fed.

TABLE III

Liver and muscle glycogen and total lipids of fed and fasted red tilapias.

\begin{tabular}{|c|c|c|c|c|c|}
\hline & \multicolumn{2}{|c|}{ Glycogen (\%) } & \multicolumn{2}{|c|}{ Total Lipid (\%) } \\
\hline & & Liver & Muscle & Liver & Muscle \\
\hline \multicolumn{2}{|c|}{ Fed } & $15.0 \pm 0.4$ & $0.52 \pm 0.03$ & $10.5 \pm 0.4$ & $4.1 \pm 0.3$ \\
\hline \multirow{7}{*}{$\begin{array}{c}\text { Fasted } \\
\text { (days) }\end{array}$} & 7 & $9.1 \pm 1.0 *$ & $0.51 \pm 0.06$ & $12.3 \pm 0.98$ & $3.8 \pm 0.3$ \\
\hline & 15 & $8.3 \pm 0.9^{*}$ & $0.48 \pm 0.05$ & $14.6 \pm 1.7^{*}$ & $3.3 \pm 0.4$ \\
\hline & 30 & $7.8 \pm 0.5^{*}$ & $0.49 \pm 0.03$ & $16.1 \pm 0.6^{*}$ & $3.5 \pm 0.2$ \\
\hline & 60 & $7.4 \pm 0.8 *$ & $0.30 \pm 0.03^{*}$ & $14.1 \pm 1.0^{*}$ & $3.1 \pm 0.3$ \\
\hline & 90 & $5.9 \pm 0.4^{*}$ & $0.31 \pm 0.03^{*}$ & $21.3 \pm 1.0^{*}$ & $2.7 \pm 0.2 *$ \\
\hline & 150 & $6.7 \pm 0.6^{*}$ & $0.40 \pm 0.04$ & $22.1 \pm 3.3^{*}$ & $2.2 \pm 0.3^{*}$ \\
\hline & 200 & $6.8 \pm 0.5^{*}$ & $0.40 \pm 0.05$ & $21.0 \pm 2.0^{*}$ & $1.5 \pm 0.1 *$ \\
\hline
\end{tabular}

Values represent mean \pm SEM ( $\mathrm{n}=10$ fish for fed and for each fasting period). * $(\mathrm{P}<0.05)$ vs fed. 

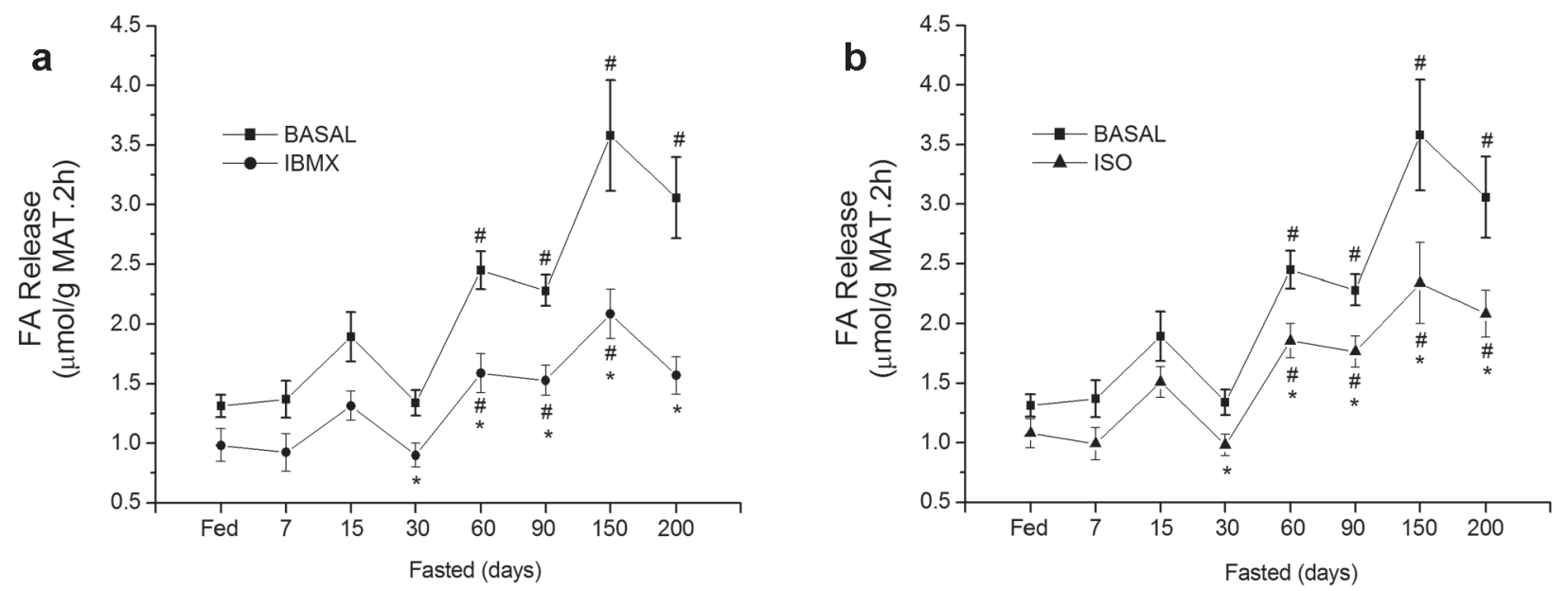

Figure 2 - Fatty acids (FA) mobilization (mmol.g ${ }^{-1}$ MAT.2h) from mesenteric adipose tissue (MAT) of fed and fasted red tilapia (Oreochromis sp) in basal condition ( $\bullet$ ) or in presence of $10^{-3} \mathrm{M} \operatorname{IBMX}(\bullet)(\mathbf{a})$ or $10^{-5} \mathrm{M} \operatorname{ISO}(\boldsymbol{\Delta})(\mathbf{b})$. * (P<0.05) vs basal; \# $(\mathrm{P}<0.05)$ vs fed. Values are mean \pm SEM ( $\mathrm{n}=10$ fish for fed and for each fasting period). IBMX: 3-isobutyl-1-methylxanthine; ISO: isoproterenol.

incubated in the presence of IBMX, an inhibitor of a cAMP-phosphodiesterase (Fig. 2a), or in presence of ISO, a non-selective beta-adrenoceptor agonist (Fig. 2b). MAT fragments of fasted tilapia, but not those collected from fed tilapias, incubated in the presence of IBMX or ISO showed a significant decrease in FFA release in comparison to MAT fragments incubated in control condition (Fig. 2).

We also found that fed tilapia MAT incubated with alpha 1 and alpha 2 adrenergic receptor agonists and antagonists, and some of their combinations, promoted a MAT lipolysis decrease (Fig. 3). Fatty acids mobilization from fragments of red tilapia MAT, fed and fasted up to 30 days, incubated in the presence of phenylephrine (PHE, $\left.10^{-5} \mathrm{M}\right)$, showed that the lipolysis inhibition of this non-selective alpha-adrenoceptor agonist was 55\% for fed fishes and $62 \%$ for 15 days fasted fishes (data not shown).

\section{DISCUSSION}

Ectotherms, which have relatively low basal metabolic rates, store substantial amounts of lipid in liver and MAT (Albalat et al. 2005). Few studies have analyzed the FFA release and the endocrine control of lipolysis in fish (Murat et al. 1981, Van den Thillart et al. 2001, Vianen et al. 2002, Albalat et al. 2005). In this study, the FFA release and its control were investigated using red tilapia as a model.

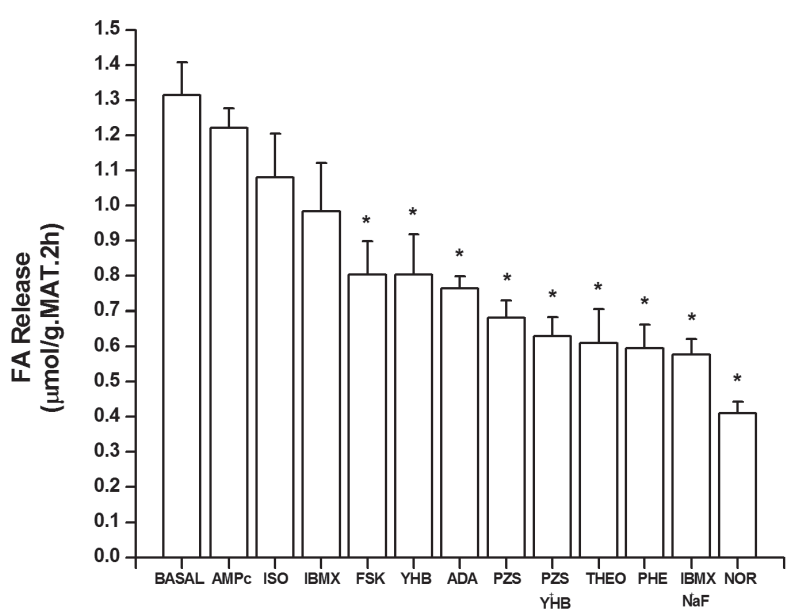

Figure 3 - Fatty acids (FA) mobilization (mmol.g ${ }^{-1}$ MAT.2h) from mesenteric adipose tissue (MAT) of fed red tilapia (Oreochromis sp) to the incubation medium in presence of several lipolytic agents: basal condition (BASAL); dibutyrylcAMP (AMPc $10^{-3} \mathrm{M}$ ); isoproterenol (ISO $10^{-5} \mathrm{M}$ ); 3-isobutyl1-methylxanthine (IBMX $\left.10^{-3} \mathrm{M}\right)$; Forskolin (FSK 10-5 $\mathrm{M}$ ); Yohimbine (YHB $\left.10^{-5} \mathrm{M}\right)$; Adenosine deaminase (ADA) $(10 \mu \mathrm{g}$. $\left.\mathrm{mL}^{-1}\right)$; Prazosin $\left(\mathrm{PZS} 10^{-5} \mathrm{M}\right)$; Prazosin $\left(10^{-5} \mathrm{M}\right)+$ Yohimbine $\left(10^{-5} \mathrm{M}\right)$; Theophylline (THEO $10^{-2} \mathrm{M}$ ); Phenylephrine (PHE $\left.10^{-5} \mathrm{M}\right)$; 3-isobutyl-1-methylxanthine (IBMX $\left.10^{-3} \mathrm{M}\right)+$ $\mathrm{NaF}(10 \mathrm{mM})$; Arterenol (NOR $\left.10^{-5} \mathrm{M}\right)$. * $(\mathrm{P}<0.05)$ vs basal. Values are mean \pm SEM ( $\mathrm{n}=10$ fish). 
The condition factor parameter was used to verify the uniformity of the fish used in this work during the different periods of fasting. The condition factor reflects the recent feeding condition or the waste of energy reserves. Changes in these values indicate alterations in the nutritional conditions of animals (Bruton and Allanson 1974, Vazzoler 1996). Only after 60 days of fasting, we observed a reduction in the condition factor. These data are in agreement with other studies carried out with tilapia (Oreochromis mossambicus) and channel catfish (Ictalurus punctatus) that showed a low condition factor after 45 days of reduced food availability (Uchida et al. 2003, Peterson and Small 2004).

Hepatosomatic index reflects alterations in the metabolic activity of the liver, acting as an appropriate biomarker of the effect of an altered environment (Rossi et al. 2015). The decrease in liver weight and hepatosomatic index after 15 and 7 days of fasting, respectively, observed in this work corroborate the data obtained previously (Rossi et al. 2015, Bayir et al. 2011, Costas et al. 2011, Barcellos et al. 2010, Pérez-Jiménez et al. 2007, Albalat et al. 2005), indicating that food deprivation significantly affects the metabolic status of fish. In addition, 7 days of fasting seems to be sufficient to completely empty the tilapia gut, since reduction of stomach and gut (SG) weight stabilized after 7 days of fasting. These values agree with the data of Figueiredo-Garutti et al. (2002) using Brycon cephalus, a carnivorous fish. The stomach somatic index of this fish species decreased $11 \%$ after $24 \mathrm{~h}$ and the gut somatic index decreased $40 \%$ after 72 $\mathrm{h}$ of fasting, remaining constant during 15 days of fasting. Gastric emptying in B. cephalus occurred faster than in red tilapia, as a result of shorter gut of the carnivorous fish (Figueiredo-Garutti et al. 2002). The stomach and gut weight loss observed in this work with red tilapias submitted to prolonged periods of fasting (60 to 200 days) also suggests that these tissues can be mobilized to supply substrates to energy metabolism.
The adaptation of several fish species to long periods of fasting is explained by use of glucose from hepatic glycogenolysis and gluconeogenesis (Machado et al. 1989). The metabolic changes during fish fasting are characterized by a sequential utilization of glycogen, lipid and protein reserves (Collins and Anderson 1995). It has been reported that 3 days without food is enough to induce a decrease in B. cephalus liver glycogen (FigueiredoGarutti et al. 2002). In the present study, tilapia hepatic glycogen content start reducing during 7 days of fasting, as well as the hepatosomatic index. This pattern may reflect the mobilization of glycogen stores to replace the absence of dietary carbohydrate intake. The plasma glucose levels were kept constant and similar to fed fish until 60 days fasting, similar to what was observed in wolf fish (Hoplias malabaricus), a Brazilian carnivorous fish (Machado et al. 1989). Gluconeogenic substrates, as amino acids mobilized from peripheral tissues (white skeletal muscle, for example) and glycerol released, as a result of the rise on lipolysis rate during fasting, could also contribute for the glycemia maintenance in tilapias (Jørgensen et al. 2002). In conclusion, the glycemia maintenance during fasting could be related to (i) the capacity of hepatic glycogen mobilization, mainly during the initial period of fasting, (ii) the activation of hepatic gluconeogenesis and (iii) the reduction of glucose use (Moon and Foster 1995).

A significant glycemia reduction in red tilapias only occurred after 60 days of fasting, remaining constant until 200 days of fasting. From 60 days until 150 days of fasting, it was observed a FFA plasma levels increase and a MAT weight reduction, indicating a mobilization of tilapia lipid reserves in these periods of fasting. Fatty acid mobilization from MAT in 60 days fasted fish was almost 2 times higher than values in fed fish. These values are still higher after longer periods without food. Conversely, after 200 days of fasting, FFA levels returned to control values. It suggests that, under 
prolonged starvation, the resting metabolism of tilapia could decrease markedly (Beamish 1964, Inui and Ohshima 1966, Mehner and Wieser 1994), downregulating the lipolysis pathway. Rossi et al. (2015) observed a marked and significant decrease in Hoplosternum littorale plasma triglyceride and hepatic lipid content, indicating that the lipidreserve could also be accessed during starvation. In contrast, Lewis and Epple (1984), studying eels (Anguilla rostrata) fasted for 6 months, did not find significant alterations in abdominal fat stores, serum glucose, liver and muscle glycogen and fatty acids when compared with fed eels. These data show the wide different metabolic responses to prolonged periods without food among fish species.

No difference was observed between fed and fasted fish in plasma lactate levels. These results corroborate a low difference in muscle glycogen content between fed and fasted fish and suggest a reduced capacity for gluconeogenesis metabolism from lactate in these animals during food deprived periods, since the plasma lactate allow that the gluconeogenesis occur in the liver via the Cori cycle. Similar results were found in other species of fish, such as Artic charr (Salvelinus alpinus), after 140 days of fasting (Jørgensen et al. 2002). In contrast, high plasma FFA levels are a characteristic marker of food restriction in fish (Farbridge and Leatherland 1992a, b, Pottinger et al. 2003), which could be used as the main energetic substrates by peripheral tissues.

Comparing the effect of known lipolytic agents in mammals, such as IBMX and ISO, in fatty acids release from tilapias MAT, it was observed that both drugs promoted a significant decrease in fatty acids release to the medium after 30 to 200 days of fasting, when compared to lipid mobilization observed in absence of these substances. Moreover, IBMX, ISO and cAMP do not present any effect on MAT lipolysis of fed tilapia. On the other hand, FSK, YHB, ADA, PZS, PZS plus YHB, THEO, PHE, IBMX plus NaF and NOR showed a clear reduction in FFA mobilization from MAT of fed tilapia. In contradiction, it was demonstrated that ISO do not alter the FFA mobilization rate in fish, amphibians and reptiles adipose tissue (Migliorini et al. 1992, Farkas 1967). On the other hand, the lipolytic activity of these tissues is higher in presence of cAMP or xanthine derivatives, cAMPphosphodiesterase inhibitors, since cAMP activates a triglyceride lipase in mammals (Migliorini et al. 1992). Our results corroborate with previous studies that demonstrated that noradrenaline and ISO inhibit lipolysis trough beta-adrenoceptors (Vianen et al. 2002, Van den Thillart et al. 2001). The reason to the contradictory effect of these drugs observed on tilapias remains elusive. Further experiments, using alpha and beta-adrenoceptors agonists and antagonists and measurements of nucleotide cyclic concentration in adipose tissue, should be done to clarify the physiological importance of these findings. The physiological signal that promotes fatty acid mobilization from adipose tissue deposits in fish remains elusive.

In summary, the results obtained in this work suggest that in tilapia the metabolic adjustment to fasting is characterized by a sequential utilization of glycogen and lipid reserves. In agreement with the increase in plasma free fatty acids, there was a clear increase in the lipolytic activity of fasted tilapia MAT incubated in vitro, indicating a significant contribution of this tissue to lipid mobilization. We also observed that the increase of fasting period lead to decrease in mesenteric adipose tissue, increase in MAT lipolysis rate and increase in lipid storage in liver. This could be a result of the high levels of FFA released during MAT lipolysis that are esterified with glycerophosphate in the liver, leading to triglycerides accumulation in this organ (Gaylord et al. 2001). The in vitro experiments with beta-agonist (ISO) and with a cAMPphosphodiesterase inhibitor (IBMX) also show that in tilapia these drugs reduce the lipolysis of fasted fish, corroborating other studies (Vianen et al. 
2002, Van den Thillart et al. 2001). Taking together, these data suggest that the reduction of lipolysis by adrenergic agonists during stressful situations, such as long periods of fasting, may represent a mechanism to prolong the life span of this specie, by preserving the adipose tissue energy reserve. These data also reinforce previous evidence that catecholamines, different from mammals, are not the lipolytic signal to enhance FFA mobilization during food deprivation in fish (Farkas 1967, Migliorini et al. 1992).

\section{ACKNOWLEDGMENTS}

The authors thank Elza Aparecida Filippin and Maria Antonieta R. Garófalo for their technical assistance. This work was supported by grants from Fundação de Amparo à Pesquisa do Estado de São Paulo (FAPESP) and from Conselho Nacional de Desenvolvimento Científico e Tecnológico (CNPq). During this study, Walter Dias Jr received a fellowship from CNPq.

\section{RESUMO}

Mudanças adaptativas no metabolismo de carboidratos e lipídios induzidas por 7, 15, 30, 60, 90, 150 e 200 dias de jejum foram investigadas em tilápia vermelha (Oreochromis sp.). Níveis de glicose plasmática, lactato e ácidos graxos livres (FFA), glicogênio hepático e muscular, conteúdo de lipídio total e taxas de liberação de FFA de tecido adiposo mesentérico (MAT) foram mensurados. Níveis de glicose plasmática apresentaram diferenças significativas apenas após 90 dias de jejum, quando a glicemia estava $34 \%$ menor $\left(50 \pm 5 \mathrm{mg} \cdot \mathrm{dL}^{-1}\right) \mathrm{do}$ que a encontrada em peixes alimentados $\left(74 \pm 1 \mathrm{mg} \cdot \mathrm{dL}^{-1}\right)$, permanecendo relativamente constante em até 200 dias de jejum. O conteúdo de glicogênio hepático (»15\%) em tilápias alimentadas diminuiu 40\% em 7 dias de jejum. Após 60, 90 e 150 dias de jejum, níveis plasmáticos de FFA aumentaram $49 \%$, 64\% e $90 \%$, respectivamente, quando comparados com os valores obtidos para peixes alimentados. Em concordância com o aumento de FFA plasmático, o jejum induziu um aumento claro da atividade lipolítica em MAT incubada in vitro. A adição de isobutilmetilxantina (inibidor da cAMP-fosfodiesterase) e isoproterenol (agonista beta adrenérgico não-seletivo) ao meio de incubação induziu uma redução da lipólise em peixes em jejum, diferentemente do que já foi observado no tecido adiposo de mamíferos. Este estudo permitiu uma avaliação fisiológica da resposta de tilápia vermelha ao jejum.

Palavras-chave: tecido adiposo, adrenoreceptor, lipólise, glicogênio hepático.

\section{REFERENCES}

Albalat A, Gómes-Requeni P, Rojas P, Médale F, KAushik S, Vianen GJ, VAN DEN Thillart G, GUTIÉRREZ J, PÉREZ-SÁNCHEZ J AND NAVARRO I. 2005. Nutritional and hormonal control of lipolysis in isolated gilthead seabream (Sparus aurata) adipocytes. Am J Physiol Regul Integr Comp Physiol 289: 259-265.

BARCEllos L, MARQueze A, TRAPP M, QUEVEDo RM AND FERREIRA D. 2010. The effects of fasting on cortisol, blood glucose and liver and muscle glycogen in adult jundiá Rhamdia quelen. Aquaculture 300: 231-236.

BAYIR A, SirkeCIOGLU AN, BAYIR M, HALILOGLU HI, KOCAMAN EM AND ARAS NM. 2011. Metabolic responses to prolonged starvation, food restriction, and refeeding in the brown trout, Salmo trutta: oxidative stress and antioxidant defenses. Comp Biochem Physiol 159(4): 191-196.

BEAMISH FWH. 1964. Influence of starvation on standard and routine oxygen consumption. Trans Am Fish Soc 93: 103107.

BERGMEYER HU, GAWEHN K AND GRASSL M. 1974. Enzymes as biochemical reagents. In: Bergmeyer HU (Ed), Methods of Enzymatic Analysis, $2^{\text {nd }}$ ed., New York: Academic Press, New York, USA, p. 457-458.

BLIGH EG AND DYER WJ. 1959. A rapid method of total lipid extraction and purification. Can J Biochem Phys 27(8): 911-917.

BoyD CE. 2004. Farm-Level Issues in Aquaculture Certification: Tilapia. Report Commissioned by WWF. http://fisheries.tamu.edu/files/2013/09/Farm-LevelIssues-in-Aquaculture-Certification-Tilapia.pdf.

BRUTON MN AND ALLANSON BR. 1974. The growth of Tilapia mossambica Peters (Pisces, Ciclidae) in Lake Sibaya, South Africa. J Fish Biol 6: 701-715.

CArrol NV, LONGLAY RW AND RoE JH. 1956. The determination of glycogen in liver and muscle by use of anthrone reagent. J Biol Chem 220: 583-593.

Caruso G, Maricchiolo G, Micale V, Genovese L, CARUso R AND Denaro MG. 2010. Physiological responses to starvation in European eel (Anguilla anguilla): effects on haematological, biochemical, non- 
specific immune parameters and skin structure. Fish Physiol Biochem 36: 71-83.

Clark AS, Kelley RA AND Mitch WE. 1984. Systemic response to thermal injury in rats. Accelerated protein degradation and altered glucose utilization in muscle. $\mathrm{J}$ Clin Invest 74: 888-897.

Clements KD AND RAUbenheIMER. 2006. 2 - Feeding and nutrition. In: Evans DH and Claiborne JB (Eds), The physiology of fishes, Boca Raton: CRC Press, Taylor and Francis Group, Florida, USA, p. 47-82.

COLLINS AL AND ANDERSON TA. 1995. The regulation of endogenous energy stores during starvation and refeeding in the somatic tissues of the golden perch. J Fish Biol 47: 1004-1015.

COSTAS B, ARAGÃO C, RUIZ-JARABO I, VARGAS-CHACOFF L, ARJONA F, DINIS MT, MANCERA JM AND CONCEIÇÃO L. 2011. Feed deprivation in Senegalese sole (Solea senegalensis Kaup, 1858) juveniles: effects on blood plasma metabolites and free amino acid levels. Fish Physiol Biochem 37: 495-504.

DOLE VP AND MEINERTZ H. 1960. Microdetermination of long-chain fatty acids in plasma and tissues. J Biol Chem 235: 2595-2599.

FARBRIDGE KJ AND LEATHERLAND JF. 1992a. Plasma growth hormone levels in fed and fasted rainbow trout (Oncorhynchus mykiss) are decreased following handling stress. Fish Physiol Biochem 10: 67-73.

FARBRIDGE KJ AND LEATHERLAND JF. 1992b. Temporal changes in plasma thyroid hormone, growth hormone and free fatty acid concentrations, and hepatic 5'-monodeiodinase activity, lipid and protein content during chronic fasting and re-feeding in rainbow trout (Oncorhynchus mykiss). Fish Physiol Biochem 10: 245-257.

FARKAS T. 1967. The effect of catecholamines and adrenocorticotropic hormone on blood and adipocyte tissue FFA levels in the fish Cyprinus carpio L. Prog Biochem Pharmacol 3: 314-319.

FigueIREDO-GARUTTI ML, NAVARro I, CAPILla E, SOUZA RHS, MORAES G, GUTIÉRREZ J AND VIVENTI-PAULINO MLM. 2002. Metabolic changes in Brycon cephalus (Teleostei, Characidae) during post-feeding and fasting. Comp Biochem Phys A 132: 467-476.

GAYLORD TG, MACKENZIE DS AND GATLIN III DM. 2001. Growth performance, body composition and plasma thyroid hormone status of channel catfish (Ictalurus punctatus) in response to short-term feed deprivation and refeeding. Fish Physiol Biochem 24: 73-79.

Hung SSO AND STOREBAKKEN T. 1994. Carbohydrate utilization by rainbow trout is affected by feeding strategy. J Nutr 124: 223-229.

INUI Y AND OHSHIMA Y. 1966. Effect of starvation on metabolism and chemical composition of eels. Bull Jpn Soc Sci Fish 33: 181-189.
JøRGENSEN EH, ViJAYAN MM, ALURU N AND MAULE AG. 2002. Fasting modifies Aroclor 1254 impact on plasma cortisol, glucose and lactate responses to a handling disturbance in Artic charr. Comp Biochem Phys C 132: 235-245.

KITTILSON JD, REINDL KM AND SHERIDAN MA. 2011. Rainbow trout (Oncorhynchus mykiss) possess two hormone-sensitive lipase-encoding mRNAs that are differentially expressed and independently regulated by nutritional state. Comp Biochem Physiol A 158: 52-60.

KROGDAHL $\AA$ AND BAKKE-MCKELLEP A. 2005. Fasting and refeeding cause rapid changes in intestinal tissue mass and digestive enzyme capacities of Atlantic salmon (Salmo salar L.). Comp Biochem Physiol A 141: 450-460.

LEWIS TL AND EPPLE A. 1984. Effects of fasting, pancreatectomy, and hypophsectomy in the yellow eel, Anguila rostrata. Gen Comp Endocr 55(2): 182-194.

LI MH AND ROBINSON EH. 2015. 4 - Complete feedsintensive systems. In: Davis DA (Ed), Feed and Feeding Practices in Aquaculture, Sawston: Oxford, Woodhead Publishing, Cambridge, UK, p. 111-126.

MACHAdO CR, GAROFAlO MAR, Roselino JES, KETTELHUT IC AND MigLiORINI RH. 1989. Effect of fasting on glucose turnover in a carnivorous fish (Hoplias sp.). Am J Physiol 256: R612-R615.

MAGNONi L, VAILlANCOURT E AND WEBER JM. 2008. In vivo regulation of rainbow trout lipolysis by catecholamines. J Exp Biol 211: 2460-2466.

MEHNER T AND WIESER W. 1994. Energetics and metabolic correlates of starvation in juvenile perch (Perca fluviatilis). J Fish Biol 45: 325-333.

MIGLIORINI RH, LIMA-VERDE JS, MACHADO CR, CARDONA GMP, GARÓFALO MAR AND KETTELHUT IC. 1992. Control of adipose tissue lipolysis in ectotherm vertebrates. Am J Physiol Regul Integr Comp Physiol 263: R857-R862.

MOON TW AND FOSTER GD. 1995. Tissue carbohydrate metabolism, gluconeogenesis, and hormonal and environmental influences. In: Hochachka PW and Mommsen TP (Eds), Biochemistry and Molecular Biology of Fishes, vol. 4., Amsterdan: Elsevier Science, Netherlands, p. 393-434.

MURAT JC, PLISETSKAYA EM AND WOO NYS. 1981. Endocrine control of nutrition in cyclostomes and fish. Comp Biochem Phys A 68: 149-158.

NAGAY M AND IKEDA S. 1972. Carbohydrate metabolism in fish. III. Effect of dietary composition on metabolism of glucose U- ${ }^{14} \mathrm{C}$ in carp. Bull Jpn Soc Sci Fish 38: 137-143.

NAVARRO I AND GUTIÉRREZ J. 1995. Fasting and starvation. In: Hochachka PW and Mommsen TP (Eds), Biochemistry and Molecular Biology of Fishes, Amsterdam: Elsevier, Netherlands, p. 393-434.

NRC - NATIONAL RESEARCH COUNCIL. 2011. Nutrient requirements of fish and shrimp. The National Academies Press, Washington DC, USA, 370 p. 
PÉREZ-JiMÉNEZ A, CARDENETE G, HIDALGO MC, GARCÍAAlcázar A, ABellán E ANd Morales AE. 2012. Metabolic adjustments of Dentex dentex to prolonged starvation and refeeding. Fish Physiol Biochem 38: 11451157.

PÉREZ-JiMÉNEZ A, GuEdes MJ, MORALES AE AND OLIVATELES A. 2007. Metabolic responses to short starvation and refeeding in Dicentrarchus labrax. Effect of dietary composition. Aquaculture 265: 325-335.

PETERSON BC AND SMALL BC. 2004. Effects of fasting on circulating IGF-binding proteins, glucose, and cortisol in channel catfish (Ictatlurus punctatus). Domest Anim Endocrin 26: 231-240.

POTTINGER TG, RAND-WEAVER M AND SUMPTER JP. 2003. Overwinter and re-feeding in rainbow trout: plasma growth hormone and cortisol levels in relation to energy mobilization. Comp Biochem Phys B 136: 403-417.

Rossi A, CAzEnAVE J, BACCHETtA C, CAMPANA M AND PARMA MJ. 2015. Physiological and metabolic adjustments of Hoplosternum littorale (Teleostei, Callichthyidae) during starvation. Ecol Indic 56: 161-170.

SCORVO FILHO JD, FRASCÁ-SCORVO CMD, ALVES JMC AND SOUZA FRA. 2010. A tilapicultura e seus insumos, relações econômicas. Rev Bras Zootec 39: 112-118.

UCHIDA K, KAJIMURA S, RILEY LG, HIRANO T, AIDA K AND GRAU EG. 2003. Effects of fasting on growth hormone/ insulin-like growth factor I axis in the tilapia, Oreochromis mossambicus. Comp Biochem Phys A 134: 429-439.

VAN DEN THILlart G, ViANEN G, PONCE MC, LELIEVELD H, NiEVEEN M, VAN RAAIL M, STEFFENS A AND ZAAGSMA J. 2001. Differential role of adrenoceptors in control of plasma glucose and fatty acids in carp, Cyprinus carpio (L.). Am J Physiol Reg Integr Comp Physiol 281: R615-R624.

VAN RAAIJ MTM, VAN DEN THILLART G, HALLEMEESCH M, BALM PHM AND STEFFENS AB. 1995. Effect of arterially infused catecholamines and insulin on plasma glucose and free fatty acids in carp. Am J Physiol Regul Integr Comp Physiol 268: R1163-R1170.

VAZZOLER AEAM. 1996. Biologia da reprodução de peixes teleósteos: teoria e prática. Maringá: EDUEM, 169 p.

VIANEN GJ, OBEls PP, VAN DEN THILlaRT GE AND ZAAGSMA J. 2002. Beta-Adrenoceptors mediate inhibition of lipolysis in adipocyte of tilapia (Oreochromis mossambicus). Am J Physiol - Endocrinology and Metabolism 282: E318-325.

Vigliano F, QUiRoga M AND NiETO J. 2002. Metabolic adaptation to food deprivation and refeeding in fish. Rev Ictiol 10: 79-108.

WEIL C, LEFÈVRE F AND BUGEON J. 2013. Characteristics and metabolism of different adipose tissues in fish. Rev Fish Biol Fisheries 23: 157-173. 